IZA DP No. 9865

Job Displacement Insurance:

A Policy Typology

Donald O. Parsons

April 2016 


\title{
Job Displacement Insurance: A Policy Typology
}

\author{
Donald O. Parsons \\ George Washington University \\ and IZA
}

\section{Discussion Paper No. 9865 \\ April 2016}

\author{
IZA \\ P.O. Box 7240 \\ 53072 Bonn \\ Germany \\ Phone: +49-228-3894-0 \\ Fax: +49-228-3894-180 \\ E-mail: iza@iza.org
}

\begin{abstract}
Any opinions expressed here are those of the author(s) and not those of IZA. Research published in this series may include views on policy, but the institute itself takes no institutional policy positions. The IZA research network is committed to the IZA Guiding Principles of Research Integrity.

The Institute for the Study of Labor (IZA) in Bonn is a local and virtual international research center and a place of communication between science, politics and business. IZA is an independent nonprofit organization supported by Deutsche Post Foundation. The center is associated with the University of Bonn and offers a stimulating research environment through its international network, workshops and conferences, data service, project support, research visits and doctoral program. IZA engages in (i) original and internationally competitive research in all fields of labor economics, (ii) development of policy concepts, and (iii) dissemination of research results and concepts to the interested public.
\end{abstract}

IZA Discussion Papers often represent preliminary work and are circulated to encourage discussion. Citation of such a paper should account for its provisional character. A revised version may be available directly from the author. 
IZA Discussion Paper No. 9865

April 2016

\section{ABSTRACT}

\section{Job Displacement Insurance: A Policy Typology}

Efforts to insure long-tenured displacement workers against earnings losses from unemployment spells and lower wages on subsequent jobs have led to an array of government and employer programs. A policy typology is proposed to impose order on these programmatic efforts. The basic typology involves the familiar distinction between (i) separation benefit type - fixed sum severance or unemployment-linked - and (ii) financing type - insurance or savings. In this four-way categorization, severance savings accounts are the least familiar, perhaps because they are often mislabeled as unemployment insurance savings accounts (UISA). A third policy dimension - the job separation events that trigger plan payouts - is also fundamental to understanding program performance and consequences. Indeed insurance plan performance converges on that of savings plans as the range of insured events and their likelihoods expand. Severance "savings" plans require payouts other than for involuntary separation, most commonly for retirement, which highlights the link with pensions. Conversely the severance properties of pension plans vary with ownership rights (vesting) and "rollover" rules. Forced savings plans that also permit fund access for house purchases and/or human capital investments (provident funds) are an obvious extension of strict severance savings plans.

JEL Classification: J65, J41, J33

Keywords: job displacement, unemployment insurance, severance pay, moral hazard, job turnover, pensions, provident funds

Corresponding author:

Donald O. Parsons

Economics Department

George Washington University

2115 G Street NW, Monroe 368

Washington, DC 20052

USA

E-mail: dopars@gwu.edu 
"Before I built a wall I'd ask to know what I was walling in or walling out..." ---Robert Frost, "Mending Walls"

\section{Introduction}

Job displacement often imposes heavy losses on long-tenured workers, both through spells of unemployment and through reduced wages on the next job. ${ }^{1}$ The ideal job displacement insurance package would include both wage insurance and unemployment insurance. ${ }^{2}$ Internationally many governments directly provide unemployment insurance and yet more mandate service-linked severance benefits as a crude, but administratively inexpensive, form of consumption smoothing. ${ }^{3}$ Wage insurance plans appear infeasible, although economists have proposed and debated various simple wage-loss-offset mechanisms. ${ }^{4}$

Economists have long expressed concerns about the search moral hazard (SMH) that $\mathrm{UI}$ benefits may induce--the unemployed may ease their job search intensity and perhaps ignore job offers that they would otherwise accept. ${ }^{5}$ Other economists have expressed concerns about firing cost distortions; if firms self-finance separation benefits, they may not release workers as efficiency would dictate, which is labeled here layoff moral hazard (LMH). ${ }^{6}$ Alternative approaches, particularly savings plans, have been advocated as solutions to both search and layoff (firing cost) concerns. For example, economists have argued for replacing unemployment insurance with unemployment insurance savings accounts (UISA), Feldstein and Altman (1998, 2007), Stiglitz and Yun (2005), and Brown,

${ }^{1}$ Surveys of the U.S. displacement loss literature include Jacobson, LaLonde, and Sullivan (1993), Fallick (1996), Kletzer (1998), and Farber (2005). See Kuhn (2002) for an international perspective.

2 Parsons (2015) provides an overview of job displacement insurance.

${ }^{3}$ Holzmann, Pouget, Weber, and Vodopivec (2012) provide a summary and review of mandated severance plans.

${ }^{4}$ See Baily, Burtless, and Litan (1993) for an early proposal, and Parsons (2000), Kletzer and Rosen (2006), Kling (2006), and LaLonde (2007) for discussion.

5 Holmlund (1998), Karni (1999), and Fredriksson and Holmlund (2006) provide extensive reviews of this literature.

6 The empirical firing cost literature is voluminous. Buechtemann (1992) provides an accessible introduction to the debate. See Heckman and Pages (2004) and Parsons (2012a) for recent reviews. 
Orszag, and Snower (2008). Lazear (1990) notes that bonding, which translates into a savings plan in a multiperiod model, Parsons (2012b), can eliminate the distortionary effects of mandated severance plans.

Other things equal, insurance is preferred to savings as a method of consumption smoothing in the face of large, low probability losses such as job displacement of longtenured workers, but other things may not be equal. Unemployment insurance savings accounts provide workers with ownership rights in their unemployment benefits and may alleviate search moral hazard. In a parallel fashion, separation (unemployment or severance) savings plans create no firing cost distortions (layoff moral hazard), even if financed by the firm.

The variety of existing and proposed separation policies makes it important to define carefully the policy alternatives, and the objective of this paper is the development of a classification scheme that provides some order to these choices. In the next section, a fourway classification of programs based on (1) the benefit payout scheme-fixed severance or unemployment-linked--and (2) the financing scheme-insurance or savings--is developed, and common moral hazard concerns in each case highlighted. The least familiar of the four types is severance savings accounts, perhaps because such plans are often mislabeled as unemployment insurance savings accounts; it is given individual attention in Section III.

A third policy dimension, the job separation events that trigger insurance benefit payouts ("benefit eligibility") and/or access to forced savings, is introduced in Section IV. Beyond the obvious--that it is important to know what events are "covered" by the consumption-smoothing instrument--the bundle of job separation events that trigger payouts has important implications for both consumption stability and moral hazard concerns. Indeed insurance plan performance converges on that of savings plans as the range of insured events and their likelihoods expand. The array of job separation triggers found in voluntary severance plans (U.S.) and mandated plans (much of the rest of the world) is then reviewed in Section V; insurance plans predominate, but severance savings plans are not unknown. 
Severance savings plans must specify fund-access events in most circumstances, ideally 100 percent of the time, not just at job displacement (permanent layoff); otherwise they would be insurance plans. Retirement is the most common of these alternative payout events, highlighting the close relationship between severance savings accounts and pensions. The roles of pensions as severance savings plans and of severance savings plans as pensions are developed in Section VI. The discussion concludes with consideration of forced savings plans that offer additional qualifying events for savings account access, including for example investments in human capital or the purchase of a house, Section VII. Examples are drawn from provident funds common in Southeast Asia and also from the U.S. 401(k) retirement savings program. A few principles underlying these choices are developed. Section VIII concludes.

\section{A Four-way Typology of Benefit and Financing Types}

Separation plans can be usefully organized around the nature of the benefits offered and the schemes by which the benefits are financed. Two familiar dichotomies are (1) unemployment-linked vs. severance benefits, and (2) insurance vs. savings financing. Severance pay can be viewed, in part, as scheduled wage insurance, in part as scheduled unemployment insurance (partial if some unemployment-linked benefits are offered). The financing of benefits is a quite distinct policy decision. ${ }^{7}$

Four variants of separation consumption smoothing policies emerge from these two dichotomies:

\begin{tabular}{|l|l|l|c|c|}
\hline & & & \multicolumn{2}{|c|}{ FINANCING INSTRUMENT } \\
\hline & & & INSURANCE & SAVINGS \\
\hline & & & & \\
\hline UNEMPLOYMENT LINKED & YES & & UI & UISA \\
\hline BENEFITS & NO & SEV & SEVSA \\
\hline
\end{tabular}

\footnotetext{
${ }^{7}$ Because most European systems combine government operated unemployment insurance benefits with mandated, firm-financed severance benefits, it is easy to confuse benefit type with funding source, as in Blanchard and Tirole (2008).
} 
Defining each more carefully, we have:

Insurance. Benefits payouts conditional on the realization of a specified stochastic event:

Unemployment insurance (UI). Payments that are conditional on both job separation and unemployment experience. These are typically periodic payments, presumably coincident with the unfolding unemployment.

Severance pay (insurance) plan (SEV). Separation payments that are conditional only on job separation. These are fixed in value at separation, but may be paid in a lump sum or as periodic payments.

Savings accounts. ${ }^{8}$ These involve contributions to a worker asset account that can be disbursed to the worker under a variety of conditions; common restrictions include the following two types of funds:

Unemployment insurance savings accounts (UISA). Savings plans with access to funds contingent on unemployment or, at end of worklife, retirement. Access would presumably be periodic, coincident with the unfolding unemployment.

Severance savings accounts (SEVSA). Savings plans with access to funds contingent on job separation (with or without unemployment) or, at end of worklife, retirement.

Of these four categories, the best known is unemployment insurance, with benefits paid out to separated workers who suffer unemployment spells. A difficulty that administrators face, even in highly developed countries, is that unemployment is an outcome of decisions by workers on search intensity and on wage offer acceptance. These decisions may change with insurance (search moral hazard). A commonly advocated policy that would eliminate the search moral hazard problem is unemployment insurance savings accounts (UISA), with workers permitted to withdraw resources as their unemployment spells lengthen. Rational, non-credit-constrained workers would have no artificial incentive to reduce search activity nor ignore job offers, because the money is theirs whether they remain unemployed or not. ${ }^{9}$

Alternatively one could eschew the possibility of loss-related benefits and offer a lump sum at job separation, corresponding perhaps to the average unemployment and earnings losses suffered by a displaced worker-that is severance (insurance) pay. A negative aspect of this approach is that benefits are only crudely linked to earnings losses,

\footnotetext{
${ }^{8}$ These savings accounts may be notional or fully funded, perhaps even held by the government or financial institutions.

${ }^{9}$ One problematic aspect of this solution is that this argument has force only if workers are rational and not credit constrained. These conditions raise questions about the reasons savings are forced in the first place.
} 
with those fortunate enough to find their next job quickly, perhaps immediately, overcompensated for their earnings losses, while those who linger in unemployment are undercompensated. Because benefits do not increase if workers linger in unemployment status, no search moral hazard concerns arise.

The least familiar of the four categories is severance savings plans, although these are much more common than unemployment insurance savings accounts, a fact that is disguised by a confusion in terminology.

\section{When is a UISA Plan Not a UISA Plan?}

The answer is "usually," or more specifically, "when it is a severance savings account (SEVSA)."

In UISA plans, the worker's right to access resources from his savings account is linked to the length of the unemployment spell. Indeed theorists have focused on one particular question--whether a typical string of unemployment spells will drain the worker's savings account and leave the worker with a negative balance at retirement. Few planners can imagine billing such workers for balance due, which leaves a hole in the savings optimality argument. If an unemployed worker can expect that he/she will run a deficit at retirement that will not be repaid, then moral hazard problems are unaffected by the transition to a savings account. Negative savings at retirement are projected to be relatively uncommon, Feldstein and Altman (1998, 2007), Vodopivec (2010), and Hopenhayn and Hatchondo (2012). ${ }^{10}$

This empirical prediction is irrelevant in existing "UISA" plans, which are almost always severance savings plans, not UISA plans. Withdrawal privileges are triggered by permanent job displacement and the extent of access does not vary with the worker's unemployment experience. For example, Ferrar and Riddell (2012) review a large number

10 See also Stiglitz and Yun (2005) and Brown, Orszag, and Snower (2008) for excellent recent discussions. 
of Latin American "UISAs." None are in fact UISAs. ${ }^{11}$ Of eight countries with apparent UISAs, six simply permit the worker to access the "balance on separation": Argentina, Brazil, Columbia, Panama, Peru, and Venezuela (Table 7.1, pp. 216-217). Two others place tighter, but still fixed sum, limits on withdrawal at separation. Chile permits withdrawals of one month of wages per year of service up to five months, while Ecuador permits withdrawals of three times average monthly wages in the previous year. These are clearly severance savings plans, not UISAs. Indeed Brazil, Columbia, Panama, and Peru permit borrowing against the funds for housing and sometimes health expenses, and might better be labeled provident funds, discussed further below, Section VII. By introducing severance savings plans to compensate for unemployment losses, these governments have "solved" the UI search moral hazard threat twice: (i) payment is fixed sum rather than conditioned on unemployment, and (ii) payments are financed through savings rather than insurance.

Even if separated workers can clear their accounts each time they are separated, they will not reach retirement with a negative balance. Conversely, the ability to access savings at each separation, independent of unemployment status, raises the concern that multiple bouts of job separation, with or without unemployment, will find the displaced worker with few account resources at retirement.

\section{A Third Policy Dimension: Benefit Eligibility Events}

A third policy dimension is fundamental to the adequacy of job displacement 'insurance' as well as its moral hazard consequences, namely the range of separation events that triggers insurance benefit payouts or access to forced savings. The nature of the resource access is different in the two cases, with insurance events inducing a benefit payout and the forced savings plan permitting, but not requiring, withdrawal. The forced savings aspect of the savings plans suggests that the practical difference between the two may be slight. Unless we are exclusively discussing savings programs, we will casually label both benefit eligibility events.

\footnotetext{
${ }^{11}$ Ferrar and Riddell were not interested in the definitional issue and did not note the casual use of the UISA label.
} 
As I argue elsewhere, Parsons (2012b), the fundamental nature of the program, even whether it is an insurance plan or a savings plan, depends on the range of separations that trigger benefit payouts and the likelihood of each. A multi-period severance insurance plan that pays out benefits across all separation eligibility events is a savings plan. There must be some uncovered event with positive probability of occurrence for the plan to be insurance in any meaningful sense.

There are a variety of reasons a worker may separate from a job, with quite distinct consequences for earnings losses and presumably insurance, ${ }^{12}$

(i) Quit (employee-initiated job separation);

(ii) Layoff (employer-initiated job separation without cause);

(iii) Discharge without prejudice (employer-initiated job separation with cause for unaggressive behavior), and

(iv) Discharges with prejudice (employer-initiated job separation with cause for aggressive behavior), and

(v) Other, including most prominently retirement.

This is essentially the U.S. Bureau of Labor typology extended to account for a distinction often important in severance and unemployment insurance plans, that between discharges for poor performance and discharges for aggressive behavior. A discharge without prejudice refers to the release of a worker who is unable to perform his/her job adequately, but not for lack of effort--perhaps just "no longer right for the job." The classic example of a discharge with prejudice is insubordination. Employee-initiated and employer-initiated separations are often referred to as voluntary and involuntary respectively (from the perspective of the worker). Quits are voluntary separations while layoffs refer to involuntary separations due to economic circumstances rather than worker performance.

The logic that lay behind the range of job separation events that triggers insurance support is plain enough, and involves (i) the magnitude of the worker's earning losses, and (ii) the firm's judgment on whether covering those worker losses is useful to the firm. Focusing on insurance plans, the ideal payout would be a direct function of the worker's

12 BLS current definitions can be found at: http://www.bls.gov/bls/glossary.htm. 
earnings losses. The earnings losses from job displacement, essentially permanent layoffs, have been much studied and are on average quite large for long-tenured workers. ${ }^{13}$ That workers might demand protection from such losses is certainly reasonable. Voluntary quits arise for a number of reasons, including changing family responsibilities, but, if economically motivated, are likely to involve no spells of unemployment and wage gains on the next job. A large number of job quitters have their next job lined up at the time of job separation, Parsons (1991). Benefits for voluntary separations or quits are plausibly non-positive, or zero if one cannot tax wage gainers.

Of course, a job separation involves the interaction of employers and employees and their disparate objectives--supply considerations as well as demand. Discharges or involuntary separations with cause often involve large earnings losses to the worker, but employers are reluctant to support such discharges. Gray areas exist, however. Workers discharged for gross insubordination are virtually never rewarded at discharge, while those simply unable to do the work, whether through changing work requirements or physical impairment, often qualify for support. Government supported UI programs often make the same distinction.

Recent reforms in Austria nicely capture aspects of the decision to include or exclude specific job separations in severance plans. The payouts from severance insurance plans are potentially large, especially among long-service workers, because severance benefits schedules typically mimic expected earnings losses and increase with length of service. ${ }^{14}$ These potential benefits have option value that is lost if, for example, the worker voluntarily

13 See Parsons (2015). Severance plans recognize the differences in earnings losses by tenure or years of service, often determining benefits by an algorithm that specifies benefits as a number of weeks of pay per year of service. Unemployment compensation benefits do not generally have this feature, though the maximum duration of benefits per unemployment spell may be extended for older workers.

${ }^{14}$ A typical severance benefit schedule might for example offer a given number of weeks of pay for each year of service, and can be quite substantial as are the expected earnings losses for workers with say 20 or 30 years of service.. 
leaves the firm, and perhaps starts elsewhere as a low service, low severance worker. This issue led to "reform" of the Austrian severance pay system in the early 2000 s. $^{15}$

As Hofer, Shuh, and Walch (2012, p.177) note, "In 2002, Austria reformed its employment protection legislation (EPL) regulation. The reform replaced a conventional severance payment systems with a system of individual savings accounts." Prior to the reform, Austrian employers were required to pay out benefits upon separation initiated by the employer or by agreement between the employer and the worker, Koman, Schuh, and Weber (2005). The reform changed the program from an insurance program to a savings program:

[the] employee can choose between receiving her severance payment from the central funds at once, or saving her entitlement towards a future pension. The amount will not be paid out if the employee gives notice herself...[although] the acquired claim...remains (Koman, Schuh, and Weber (2005, p.258).

The post-reform plan is perhaps best described as a severance/retirement savings account, because the worker can withdraw the money only upon involuntary separation and otherwise must wait until retirement.

One reason given for the reform was the complaints from trade unions that workers were (inefficiently) induced to forego attractive alternative jobs because they would otherwise have to forego potentially large severance payments should they be laid off in future periods. This might be labeled quit moral hazard $(\mathrm{QMH})$. The expected value of the severance pay promise would presumably be the expected benefits weighted by the likelihood that the worker would be laid off involuntarily in the future and receive severance. The importance of this effect is unclear theoretically, although Hofer, Shuh, and Walch (2012) find little evidence of change in quit behavior following reform.

For savings plans, the policy issue is to determine the events that allow the worker access to the accumulated account. Following the same logic as insurance, the simplest severance "savings" plan may include only permanent layoffs as a qualifying event for early

\footnotetext{
${ }^{15}$ Note that both pre- and post-reform plans are pure severance plans, unaffected by unemployment experience following separation.
} 
release of accumulated savings, although it is also necessary to specify the conditions under which the resources become available if the worker is not permanently laid off. The Austrian post-reform model is an obvious model-the worker is permitted access to the funds following involuntary separation, but otherwise must wait until retirement. ${ }^{16}$

\section{Separation Benefit Eligibility Events: The U.S. and Abroad}

Government unemployment support programs are largely insurance plans, with a few being severance savings plans. Voluntary severance plans are common in the United States and government mandated ones in much of the rest of the world, Parsons (2013), and it is natural to ask whether these are insurance plans or savings plans, the latter being free of firing cost or layoff moral hazard concerns.

United States. Unemployment insurance benefits in the United States are supplied through the States subject to Federal regulations, and structural details vary, though major features are common. The plans are true unemployment insurance plans, with benefits paid out only for the duration of the unemployment spell (up to a maximum number of weeks). Benefits are typically limited to involuntary separations without prejudice to the worker, although there is considerable dispute over the gray area between voluntary separations and quits induced by employer behaviors that creates an intolerable workplace.

Severance pay plans in the United States are privately supplied, largely through the employer, but also through labor unions as part of collective bargaining agreements. ${ }^{17}$ As market-determined financial instruments, severance plans in the U.S. take on a bewildering variety of forms. Characterizing the structure of severance contracts is difficult because the usual government sources, for example the Bureau of Labor Statistics, provide little information on severance pay structure in the United States. A series of large scale surveys conducted by the National Industrial Conference Board provide abundant information on

16 For a worker with a high time discount rate, the pre and post reform plans may seem similar.

17 For a history of the emergence and growth of private severance pay plans in the United States, see Parsons (2005a,2005b). Freedman (1978) provides some history of collectively bargained severance and SUB contracts. For the genesis of severance pay worldwide, see Holzmann, Pouget, Weber, and Vodopivec. (2012). 
severance pay design prior to 1980 , Parsons (2005a, 2005b), but to explore later developments we must rely on surveys conducted by private consulting firms, which tend to focus on compensation packages for upper level management workers.

The list of separation qualifying events has varied over time. The earliest formal plans, introduced on a large scale in the United States early in the Depression, were limited in scope, Hawkins (1940). Benefit status normally required that workers be involuntarily and permanently separated from the firm without prejudice to the worker, although small, notice plans were often associated with benign inefficiencies:

In forty-five of the sixty-six concerns [offering graduated plans] compensation is given only for permanent dismissal, while in the remainder it is granted for extended layoffs as well... Although many plans were originally adopted to facilitate necessary reductions in personnel, their scope has extended in a number of cases to include discharges for inefficiency, in order to eliminate individual misfits who might otherwise remain on the payroll for years. NICB [Brower] $(1937$, p.6)

In the terminology of the last section, benefit qualifying events included (permanent) layoff and, later, discharge without prejudice. Less commonly, severance plans were used to compensate workers for other reasonable separations; for example approximately $10 \%$ of the 66 companies paid severance to those separated for physical incapacity, and some used the plans as a crude form of retirement pension.

An NICB survey conducted twenty years later (1953) revealed a substantial expansion in the scope of qualifying events for benefits. Eligibility, as earlier, emphasized involuntary permanent separations initiated by the company:

All the plans provide severance pay for causes that might be considered beyond the individual's control. Among such reasons are elimination of the job, consolidation of departments, mergers, abandonment of plants, technological changes, and declining business activity. Thirty-two of the 103 plans analyzed, or about a third, grant severance pay only for such unavoidable layoffs. NICB [Forde and Brower] (1954, p.9)

However, the ancillary uses of severance pay to insure other involuntary events had expanded. "Forty plans, or nearly $40 \%$ of the total, grant severance pay for terminations due 
to disability.... Only about one in ten plans in the 1942 survey included this as a reason." 18 NICB [Forde and Brower] (1954, p.9) Negotiated union plans frequently did not require a specific departure event to make the individual eligible for severance--nineteen plans, primarily union-negotiated, even covered separation "for cause."

A Right Associates survey conducted in 1990, Right (1990) suggests that the range of qualifying events for severance benefits had again narrowed. Respondents (employers) with severance plans were asked if benefit eligibility is conditioned on one or more of the following qualifying events: reduction in force, elimination of position, discharge for performance, discharge for cause, discharge for disability, voluntary resignation, retirement with pension, and retirement without pension. The frequency of each is illustrated in Figure 1A. The primary qualifying events are reduction in force and elimination of position, each of which is covered in essentially all plans. In approximately 40 percent of the plans, discharge for performance is covered; this separation category include workers making a good faith effort to do a job, but not succeeding at it, which could be viewed as an insurable event, one for which the employer is responsible. Conversely voluntary separations and discharges for cause are rarely covered. ${ }^{19}$ Note also the absence of payments to retirees; U.S. plans are displacement insurance plans, not savings or provident funds.

$<$ figure 1>

Holzmann, Pouget, Weber, and Vodopivec (2012) recently conducted a survey of severance plans worldwide. ${ }^{20}$ Job separation packages vary widely across economies, as one would expect from the evolution of separation events covered in U.S. voluntary systems, and with a similar logic. ${ }^{21}$ The administrative convenience of severance pay-the

18 About $80 \%$ of the cooperating companies with retirement benefit plans do not give severance pay to employees whose services are terminated by retirement, except under certain circumstances." NICB [Forde and Brower] (1954, p.25)

19 Eligibility rules in union contracts are apparently much more relaxed, with voluntary departures frequently covered. NICB [Forde and Brower] 1954, pp. 9-10. Voluntary turnover in major unions at the time was of course unusual.

20 Michael Weber kindly supplied an excel file of the key table, Annex 2.

${ }^{21}$ Holzmann et al (2012) provide a detailed empirical account of variations in the size and composition of separation packages world-wide. 
government need only mandate that private employers provide the instrument--makes it especially popular. ${ }^{22}$ In a sample of 149 countries with a million or more inhabitants, 130 (87\%) had some form of mandated severance pay, including 27 that had both statutory severance and collectively bargained severance pay in a "significant manner," Holzmann et al (2012, Annex B). ${ }^{23}$ Another 13 (9\%) had only significant collective bargaining severance. ${ }^{24}$ Only six (4\%) had neither.

Unemployment insurance is more difficult to provide, and, not surprisingly, much less common. Of the 130 countries in the sample with statutory severance pay, only $61(47 \%)$ provided unemployment insurance, 69 did not. Another $8(6 \%)$ with statutory severance pay offered means-tested unemployment assistance. Of the 13 countries with only collectively bargained severance, 11 countries provided unemployment insurance and another unemployment assistance. None of the six countries that had neither statutory nor collectively bargained severance (the Democratic Republic of the Congo, Iraq, Haiti, Lebanon, Gambia, and Timor-Leste) provided unemployment insurance.

The various combinations of unemployment insurance/assistance and mandated severance pay are not random, but are closely linked to country income and presumably government competencies. GDP per capita in the six countries that had neither mandated severance or some form of unemployment insurance was $\$ 1,999$. Of the 69 countries that had only mandated severance pay and no unemployment insurance, average GDP per capita was only $\$ 5,810$. Of the 61 countries with both mandated severance and some form of unemployment benefit, the average GDP per capita (in 2009 U.S. dollars) was $\$ 14,418$.

Unemployment insurance plans target workers who involuntarily separated from the firm without prejudice or were discharged without cause, but may cover workers who voluntarily leave the firm after a penalty period of zero benefits, and sometimes even workers

22 Severance pay has its own potential limitations, the firing cost problem, discussed in Section 7 below.

23 Author's calculation from Holzmann et al (2012, Annex B).

24 This group includes the U.S., where collective bargaining agreements do often include severance pay provisions, Pita (1996), but where collective bargaining is limited. Voluntary plans are however prevalent. 
discharged for cause. ${ }^{25}$ The mix of separation events that trigger mandated severance benefits is much wider, Holzmann et al (2012). Figure 1B provides a tabulation of separation eligibility events. Redundancy is almost universal in government mandated plans. Redundancy includes "Economic reasons, Redundancy, Reduction of Staff, Retrenchment, Reorganization, Restructuring, Structural Changes, [and] Technological Changes" (p.109), combining the two largest categories in the Right Study, Figure 1B. Reflecting perhaps the difference between voluntary severance and government mandated severance, dismissals (employer reasons other than economic) are covered in half (51 percent) the countries in the sample. Disability is covered in 17 percent. End-of-service, which includes voluntary quits as well as end of contracts, is covered in 13 percent. Even fewer countries mandate plans that pay out for retirement ("old age")—-the typical signature of severance savings plans-about six percent.

That is not to say that severance savings plans are unknown internationally. As discussed early, such plans are common in Latin America, though mislabeled (under present definitions) as unemployment insurance savings accounts. The Austrian reform discussed earlier involved a transition from a severance insurance plan to a severance savings plan.

To take another example, Hur (2003) examined the Korean severance pay system, and found a savings plan, not an insurance plan. Korea mandates employer participation in a separation benefit plan that seems like a "severance pay" plan. ${ }^{26}$ However, the individual "asset" accounts accrue linearly with service, and are again paid out at the time of separation without any restrictions on the reason for departure. Even upon voluntary separation, the worker receives the money. Clearly this is a savings plan, not an insurance plan; the asset does not increase in value with an involuntary job separation; it is only paid out at that time.

\footnotetext{
${ }^{25}$ Social Security Administration, various years.

${ }^{26}$ The original Korean word for this plan apparently does not distinguish severance from retirement, with neither being an especially informative label, as will become clearer shortly.
} 


\section{Separation Pay and Pensions}

The distinction between job separation savings accounts, whether severance or unemployment-linked, and pensions or retirement savings accounts is often a subtle one. Savings accounts of any sort must release most, ideally all, worker funds sometime over the work life. Otherwise the account would be insurance, with payments stochastic. Retirement is a natural concluding event for both firm managed plans and public savings programs:

\section{Savings accounts (continued):}

Pensions or retirement savings accounts. These can take a variety of forms, but we focus here on defined contribution plans, essentially savings accounts with retirement as the obvious and perhaps exclusive permissible access events.

SEVSA (or UISA) can have pension features and "pensions" or retirement accounts can have SEVSA features. Indeed there are plan mechanisms that permit designers to choose across a continuum of severance pay-pension tradeoffs.

Consider severance plans as pensions. Public plans, like the Austrian severance system, can be seamless, permitting "early" withdrawal with involuntary separation from the firm and otherwise reserving payouts to retirement. Private firm SEVSA plans are less simple, because private firms have little interest in maintaining savings accounts until retirement for workers who quit or separate for reasons other than "involuntary separation." Under an insurance plan, any claims for benefits that these workers have are forfeit when they separate from the firm for other reasons. In a savings account, the natural response might be to release the funds to the separated worker, with the worker having the responsibility to "roll over" the funds into a retirement account. In the absence of serious monitoring of rollovers, this translates into a separation savings account, with the worker having access to the funds whatever the reason for the separation.

Recent Korean reforms lay bare the need for careful thought on the freedoms workers should have to manage (or consume) their savings. At separation, should workers be required to roll over their accounts and not use the proceeds for current needs? Obviously conversion into a restricted, retirement-only plan eliminates any consumption smoothing in response to job displacement. The 2005 reform aggressively pushed workers 
toward converting their severance savings plans into pure pension plans, Yun and Hur (2012). The pension plan limits worker access to the funds prior to retirement, specifically for expenditures on housing and long term care. The severance savings element is lost. Perhaps not surprising, conversion, which requires the approval of both the company and its workers, has been limited, Yun and Hur (2012).

SEVSA accounts are relatively uncommon and the converse question is perhaps more relevant--under what conditions do pensions serve as severance pay? The easier the pension rules on accessing accumulated savings upon early job separation, the closer the pension comes to a severance savings plan. Many pensions, both public and private, do not offer early access to account funds. In the United States, for example, access to Social Security retirement "savings" is not affected by job separation, but only by withdrawal from the labor force, and then only at age 62 , with benefits actuarially adjusted for "early" retirement. ${ }^{27}$ Private firm pensions in the U.S. are more varied, and a critical question is the events that provide access to funds at job separation.

In the U.S., there are of two types of pensions: (i) defined benefit plans which offer annuitized benefits at retirement based on some measure of the worker's prior wages (Social Security retirement benefits are of this type), and (ii) defined contribution plans, which are essentially savings accounts, familiar in the United States as employer 401(k) plans. $^{28}$ Historically, defined benefit plans dominated because of the deferred tax advantages bestowed (earlier) on that form. The question is, what happened upon separation from the firm prior to retirement? If the worker's pension rights are not "vested," these rights simply vanish. The worker suffers a capital loss, and severance pay is, in a sense, negative. Prior to ERISA (1974), such cliff vesting was common. If a plan vested at 30 years of service, the worker who left the firm at 29 years lost all pension rights, essentially negative severance pay.

\footnotetext{
27 Asset withdrawal is possible only in annuity form, which need not interest us here, but also has behavioral implications in a myopic population.

28 For a readable summary of 401(k) plans, see http://invest-faq.com/articles/ret-plan-401k.html.
} 
With ERISA, the government imposed short vesting periods in defined contribution plans and moderate vesting periods in defined benefit plans. Once vested, the separated worker in a defined benefit plan often has the option of (i) leaving the account with the separating firm, and receiving benefits at normal retirement age corresponding to his/her earnings record with the firm or (ii) cashing out of the program. ${ }^{29}$ With a defined contribution plan, the displaced worker may either "roll-over" his funds in a company plan or cash out, with the later more common. If the displaced worker rolls the funds over into a different government-approved plan within a specific time interval, there are no tax consequences.

Tax-favored pensions in the U.S. discourage withdrawal of funds before retirement. Funds withdrawn from a U.S. 401(k) plan are considered taxable income, and a second tax, a 10 percent penalty, is imposed on funds withdrawn. ${ }^{30}$ The introduction of economic penalties for withdrawal essentially generates a continuum of possible combinations of severance savings accounts and pensions, with zero sanctions creating a severance savings account, and prohibitive sanctions a pure pension. With a ten percent penalty, complete rollover of funds into a new pension is not common:

...approximately 55 percent of those who took a lump-sum payment did not roll all of it into tax-qualified savings..., although some of these distributions were used for purposes that might contribute to financial well-being; home purchases, starting businesses, or paying down debt. Copeland $(2013$, p.8)

Apparently private pensions in the U.S. do serve in part as severance savings plans.

Lazear (1983) argued that a special feature of many U.S. private pensions, the early retirement option, can be considered a form of severance pay. He noted that U.S. private pensions frequently offered early retirement options that were not fully actuarially adjusted, which is to say the pension gave the worker a reason to separate from the firm early. The quit incentives of these plans are not of interest here, but a worker covered by such a plan who is involuntarily released would benefit if in the eligible age range, often 55 or older.

\footnotetext{
${ }^{29}$ Unlike the Austrian system, there is no requirement that the separation be involuntary, which raises the possibility that the credit-constrained worker could voluntarily leave her/his job in order the secure the funds early.

30 Despite this penalty withdrawal of funds is common.
} 


\section{Provident Funds and Early Access to Forced Savings}

Forced savings plans, whether primarily SEVSA or pensions, might easily be extended to cover events other than job separation or retirement. Indeed that is exactly what provident funds do. Provident funds are compulsory savings plans that typically permit fund withdrawals under a variety of circumstances in addition to retirement, including schooling costs, starting a business, etc. ${ }^{31}$

\section{Savings accounts (continued 2):}

Provident funds. Savings plans with a potentially large number of permissible access events- house purchase, educational finance, medical expenses, job separation/unemployment, and retirement.

Consider one of India's provident funds, that for employees—the Employees' Provident Fund Organization (EPFO). The plan identifies a large number of purposes warranting early access (advance/withdrawal) by the employees of their funds, including

- $\quad$ Marriage / Education

- Treatment

- $\quad$ Purchase or construction of Dwelling house

- Repayment of Housing Loan

- $\quad$ Purchase of Plot

- Addition/Alteration of House

- Repair of House

- $\quad$ Lockout

- Withdrawal Prior to Retirement

- $\quad$ Other Advances

\section{http://www.epfochennai.tn.nic.in/advances_withdrawls.html}

Indeed the one glaring omission is access for job displacement, although there is a special provision for accessing funds during a "lockout or closure."

The design features of the optimal provident fund have, to my knowledge, not been worked out, but must involve some belief that resources must be pushed forward in time (saved), though "the devil is in the details." Any set of rules for fund access is likely to be structured around the following two principles:

1. The "prudent person" rule: what would a prudent person do with his/her savings?

2. The "administrative convenience" rule: how likely is it that the plan administrator can efficiently implement the rule?

\footnotetext{
${ }^{31}$ Asher (2009) provides an overview of provident funds.
} 
A government that decides individuals are not competent to handle their own funds must imagine an alternative decision-maker that they feel is more appropriate and they must consider whether the resulting prudence mandates are implementable. Often they are not. To illustrate the distinction in a related social insurance context, until relatively recently, the U.S. Social Security disability system did not cover mental illnesses without an accompanying physical cause. Although emotional/mental illness can be cruelly debilitating, quite clearly satisfying Rule (1), it did not, until recently, satisfy Rule (2), in this case reasonable verification.

Of course, a sufficient number of access events may thwart the whole objective of compulsory retirement savings, much less the provision of severance support. What many of these other events have in common, however, is that the funds may be used for positive events, housing opportunities, training, etc., that might make retirement easier. With the exception of the medical option, they are not associated with negative income shocks, and even the access to funds for medical expenses may have a positive human capital element.

Nonetheless a concern arises that sufficient options will leave little for the funds primary goal, be it consumption support in retirement or job displacement. Governments have found at least two ways to deal with that problem. As noted with U.S. 401(k) rules, one can impose a penalty rate on withdrawals that corresponds to the desired government emphasis on objectives. The worker is given the choice of continuing the money in the company's plan, rolling the balance over into another government approved savings instrument, or withdrawing the balance, with the 10 percent penalty noted earlier. The company may permit borrowing against the savings account. This borrowing is subject to company rules, although there is a statutory maximum, the loan amount cannot exceed 50 percent of the account value.

An alternative approach extends the idea of penalty rates across activities, by compartmentalizing forced savings, which limits the maximum withdrawal for any individual use. A paradigm program is that operating in Singapore. A description of Singapore's core provident fund is illustrative: 
Central Provident Fund (CPF) provides four types of individual accounts for each member: an ordinary account (OA) to finance the purchase of a home, approved investments, CPF insurance, and education; a special account (SA), principally for retirement (may invest in retirement related financial products); a Medisave account (MA) for certain medical expenses (see Sickness and Maternity); and a retirement account (RA) set up at age 55 to finance periodic payments at retirement. SSA (SSA Singapore, 2012)

The savings are partitioned into subaccounts, with one untouchable pool for retirement and the others contributing to retirement if otherwise unspent. Setting the fund categories and the share of resources going to each become the key design decisions.

\section{Conclusion}

Job displacement (permanent layoff) of long-tenured workers is a serious threat to earnings stability and potentially to consumption stability. While wage insurance and unemployment insurance can ideally smooth consumption in the face of job displacement, wage insurance appears infeasible and unemployment insurance is typically incomplete because of moral hazard concerns. Instead, unemployment insurance and severance have emerged worldwide as policy responses to these dual earnings threats, with many economists advocating for a third alternative, unemployment insurance savings accounts.

Clearly it is important to use care in describing the policies one is analyzing -if only to aid discourse and to make clear what is ruled in and ruled out. A simple four-way structure in benefit form (unemployment or separation pay) and financing form (insurance or savings) highlights the fact that UI, UISA and severance (insurance) plans are not the only mechanisms available to the planner--severance savings accounts are another mechanism. Indeed SEVSA have been implemented in a number of Latin American countries. Access to funds is dependent on job separation, not unemployment experience.

A third dimension is important in categorizing plans for their consumption smoothing properties and moral hazard implications, the list of separation events that trigger benefit payments (insurance) or fund access (savings). For example, the distinction between insurance and savings plans blurs as the number of insurable separation types (and their likelihoods) increase. Savings accounts require that the saver have access to his/her money at some point; because no worklife is forever, a plan that provided access across all possible 
separation events would qualify as a savings account. As it happens, voluntary severance plans in the United States are overwhelmingly insurance plans, with involuntary job separation without cause the triggering event for benefits, Figure 1a. The same is true of government mandated severance plans worldwide, Figure $1 \mathrm{~b}$, although more relaxed plans do exist.

Savings plans, whether involuntary job separation or unemployment status focused, require a payout event should these eligibility events not occur; otherwise the plan would be insurance. The alternative payout event is typically retirement, which highlights the close connection between separation savings accounts and pension plans. In that sense it is useful to consider pension plans as severance savings plans, which might smooth consumption following involuntary job separation. Forced savings plans that generalize access events to include other life-cycle demand for funds, loosely provident funds, are also likely to function as job displacement protection, although with decreasing levels of reliability as fund access events multiply.

This typology of job displacement consumption smoothing programs examines only the most common patterns. In advanced economies, in which the incomes of households can be inexpensively monitored, means-tested programs are common (social assistance plans), ${ }^{32}$ often in combination with other programs. A few programs attempt to pool savings plans across workers, at least partially, combining insurance and savings in interesting ways. In these more complex programs, much useful theorizing remains. ${ }^{33}$

\footnotetext{
${ }^{32}$ A consumption smoothing mechanism highlighted by Atkinson and Mickelwright (1991).

${ }^{33}$ See for example discussions of the Chilean system--Berstein, Fajnzylber, and Gana (2012) and Reyes, van Ours, and Vodopivec (2012)
} 


\section{REFERENCES}

Asher, Mukul G. (2009) "Provident and Pension Funds and Economic Development in Selected Asian Countries." In Mukul G. Asher, ed. Financing Social Policy: Mobilizing Resources for Social Development, New York: St. Martin's Press, 264-89.

Atkinson, Anthony B. and John Micklewright 1991 "Unemployment Compensation and Labor Market Transitions: A Critical Review." Journal of Economic Literature 29 (December): 1679-1727.

Baily, Martin Neil, Gary Burtless, and Robert E. Litan. 1993. Growth with Equity: Economic Policymaking for the Next Century, Washington, DC.: 110-141.

Berstein, Solange, Eduardo Fajnzylber, and Pamela Gana. 2012. "The New Chilean Unemployment Insurance System: Combining Individual Accounts and Redistribution in an Emerging Economy." Reforming Severance Pay: An International Perspective, Washington, D.C.: World Bank, pp. 259-84

Blanchard, Olivier J., and Jean Tirole. 2008. "The Joint Design of Unemployment Insurance and Employment Protection: A First Pass," Journal of the European Economic Association v.6(1) March: 45-77.

Brown, Alessio J. G., J. Michael Orszag, and Dennis J.Snower. 2008. "Unemployment Accounts and Employment Incentives," European Journal of Political Economy. v.24.3 (September): 587-604.

Buechtemann, C.F. ed. 1992. Employment Security and Labor Market Behavior: Interdisciplinary Approaches and International Evidence, Ithaca, NY: ILR press, Cornell University.

Copeland, Craig. 2013. "Lump-Sum Distributions at Job Change, Distributions Through 2012." Employment Benefits Research Institute Notes, vol. 34.11 (November): 2-13.

Fallick, Bruce C. 1996. "A Review of the Recent Empirical Literature on Displaced Workers," Industrial and Labor Relations Review. 50(1): 5-16.

Farber, Henry S. 2005. "What Do We Know about Job Loss in the United States? Evidence from the Displaced Workers Survey, 1984-2004." Federal Reserve Bank of Chicago Economic Perspectives. 29(2): 13-28.

Feldstein, Martin, and Daniel Altman. 1998. "Unemployment Insurance Savings Accounts." National Bureau of Economic Research, Inc, NBER Working Papers: 6860.

Feldstein, Martin, and Daniel Altman. 2007. "Unemployment Insurance Savings Accounts." Tax Policy and the Economy. v.21: 35-63.

Ferrer, Ana M. and W. Craig Riddell. 2012. "Unemployment Insurance Savings Accounts in Latin America: Overview and Assessment." In Robert Holzmann and Milan Vodopivec, eds., Reforming Severance Pay: An International Perspective, Washington, DC: World Bank, 211-237.

Fredriksson, Peter, and Bertil Holmlund. 2006. "Improving Incentives in Unemployment Insurance: A Review of Recent Research," Journal of Economic Surveys, vol.20.3: 357- 386.

Freedman, Audrey. 1978. Security Bargains Reconsidered: SUB, Severance Pay, Guaranteed Work, The Conference Board Report No. 736.

Hawkins, Everett D. 1940. Dismissal Compensation, Princeton, NJ: Princeton University Press. 
Heckman, James J., and Carmen Pagés. 2004. "Introduction," in Heckman and Pagés, eds., Law and Employment: Lessons from Latin America and the Caribbean, Chicago, The University of Chicago 1-107.

Hofer, Helmut, Ulrich Schuh and Dominik Walch. 2012. "Effects of the Austrian Severance Pay Reform," In Robert Holzmann and Milan Vodopivec, eds., Reforming Severance Pay: An International Perspective, Washington, DC: World Bank, 177-194.

Holmlund, Bertil. 1998. "Unemployment Insurance in Theory and Practice," Scandinavian Journal of Economics, 100(1): 113-141.

Holzmann, Robert, Yann Pouget, Michael Weber, and Milan Vodopivec. 2012. "Severance Pay Programs around the World: History, Rationale, Status, and Reforms" In Robert Holzmann and Milan Vodopivec, eds., Reforming Severance Pay: An International Perspective, Washington, DC: World Bank, 17-120.

Hopenhayn, Hugo, and Juan Carlos Hatchondo. 2012. "The Welfare Consequences of Alternative Designs of Unemployment Insurance Savings Accounts" Reforming Severance Pay: An International Perspective, Washington, D.C.: World Bank, pp. 239-57.

Hur, Jai-Joon. 2003. "Korean Severance Pay Reform," paper presented at the World Bank/IIASA/Ludwig Boltzmann Institute International Workshop on Severance Pay Reform: Toward Unemployment Savings and Retirement Accounts, Laxenberg/Vienna, November 7-8.

Jacobson, Louis S., Robert J. LaLonde, Daniel G. Sullivan. 1993. The Costs of Worker Dislocation, Kalamazoo, MI: W.E. Upjohn Institute for Employment Research.

Jaramillo, Miguel, and Jaime Saavedra. 2005. "Severance Payment Programs in Latin America," Empirica 32(3-4): 275-307

Karni, Edi, 1999. 2006. "Optimal Unemployment Insurance: A Survey." Southern Economic Journal, 66 (October): 442-65.

Kletzer, Lori G. 1998. "Job Displacement." Journal of Economic Perspectives v12, n1 (Winter): 115-36

Kletzer, Lori G, and Howard F. Rosen. 2006. "Reforming Unemployment Insurance for the Twenty-First Century Workforce," The Hamilton Project, Brookings Institution, Discussion Paper 2006-06 September.

Kling, Jeffrey R. 2006 "Fundamental Restructuring of Unemployment Insurance: Wage-Loss Insurance and Temporary Earnings Replacement Accounts," The Hamilton Project, Brookings Institution, Discussion Paper 2006-05 September 2006.

Koman, Reinhard, Ulrich Schuh and Andrea Weber. 2005. "The Austrian Severance Pay Reform: Toward A Funded Pension Pillar," Empirica Vol. 32(3-4): 255-274

Kuhn, Peter, ed. 2002. Losing Work, Moving On: International Perspectives on Worker Displacement, W.E. Upjohn Institute for Employment Research, Kalamazoo, Michigan.

LaLonde, Robert J. 2007. "The Case for Wage Insurance," Maurice R. Greenberg Center for Geoeconomic Studies at the Council on Foreign Relations.

http://www.cfr.org/publication/13661/case_for_wage_insurance.html,

Lazear, Edward P. 1983. "Pensions as Severance Pay," in Zvi Bodie and John B. Shoven, eds., Financial Aspects of the United States Pension System, Chicago: University of Chicago Press: 57-90.

Lazear, Edward P. 1990. "Job Security Provisions and Employment." Quarterly Journal of Economics 105 (August): 699-726. 
Lee Hecht Harrison. 2001. Severance and Separation Benefits: Bridges for Employees in Transition. Woodcliff Lake, NJ: Lee Hecht Harrison, 2001.

NICB (National Industrial Conference Board) [F. Beatrice Brower]. 1937. Dismissal Compensation, Studies in Personnel Policy, No. 1, New York.

NICB (National Industrial Conference Board) [Lois E. Forde and F. Beatrice Brower]. 1954. Severance Pay Plans. Studies in Personnel Policy No. 141, New York, National Industrial Conference Board.

Parsons, Donald O. 1991. "'The Job Search Behavior of Employed Youth", Review of Economics and Statistics (November) 597-604.

Parsons, Donald O. 2000. "Wage Insurance: A Policy Review," in Research in Employment Policy, 2: 119-140.

Parsons, Donald O. 2005a. "The Emergence of Private Job Displacement Insurance in the United States: Severance Pay Plans 1930-1954" (October): http://ssrn.com/abstract=872331.

Parsons, Donald O. 2005b. "Private Job Displacement Insurance in the United States, 19541979: Expansion and Innovation" (November): http://ssrn.com/abstract=872334.

Parsons, Donald O. 2012a. "'Mandated Severance Pay and Firing Cost Distortions: A Critical Review of the Evidence," Chapter 3 in Robert Holzmann and Milan Vodopivec, eds., Reforming Severance Pay: An International Perspective, Washington, DC: World Bank, 121-157.

Parsons, Donald O. 2012b. "The Firing Cost Implications of Alternative Severance Pay Designs," Chapter 4 In Robert Holzmann and Milan Vodopivec, eds., Reforming Severance Pay: An International Perspective, Washington, DC: World Bank, 159176.

Parsons, Donald O. 2013. "Understanding Severance Pay," Cuadernos de Economía (Spanish Journal of Economics and Finance) Elsevier. v.36, no, 106 Sept-Dec, 2013: 155-165. Draft available as "Understanding Severance Pay," IZA Working Paper 7641. http://ftp.iza.org/dp7641.pdf.

Parsons, Donald O., 2015. "Job Displacement Insurance" in James Wright, ed. International Encyclopedia of the Social and Behavioral Sciences, 2nd edition, Vol 12. Oxford: Elsevier. (March): 819-832. Draft available at http://ftp.iza.org/dp8223.pdf

Pita, Cristina. 1996. "Advance Notice and Severance Pay Provisions in Contracts, Monthly Labor Review 119 (7): 43-50.

Reyes, Gonzalo; Jan C. van Ours, and Milan Vodopivec. 2012. "Reemployment Incentives under the Chilean Hybrid Unemployment Benefit Program." Reforming Severance Pay: An International Perspective, Washington, D.C.: World Bank. pp. 285-94.

Right Associates. 1990. Severance: The Corporate Response. Philadelphia, PA: Right Associates. (November).

Social Security Administration. Various years. Social Security Programs throughout the World. http://www.ssa.gov/policy/docs/progdesc/ssptw/index.html.

Stiglitz, Joseph E., and Jungyoll Yun. 2005. "Integration of Unemployment Insurance with Retirement Insurance." Journal of Public Economics, v.89.11-12. (December): 203767.

Vodopivec, Milan. 2010. "How Viable Are Unemployment Insurance Savings Accounts? Simulation Results for Slovenia". Comparative Economic Studies, v. 52.2 (June): 225-47. 
Yun, Jungyoll, and Jai-Joon Hur. 2012. "Severance Pay Reform in Korea." In Robert Holzmann and Milan Vodopivec, eds., Reforming Severance Pay: An International Perspective, Washington, DC: World Bank, 195-210. 
Figure 1

Severance Pay: Eligible Separation Events (in Percent)

Panel A: The United States Voluntary Severance System (1990)

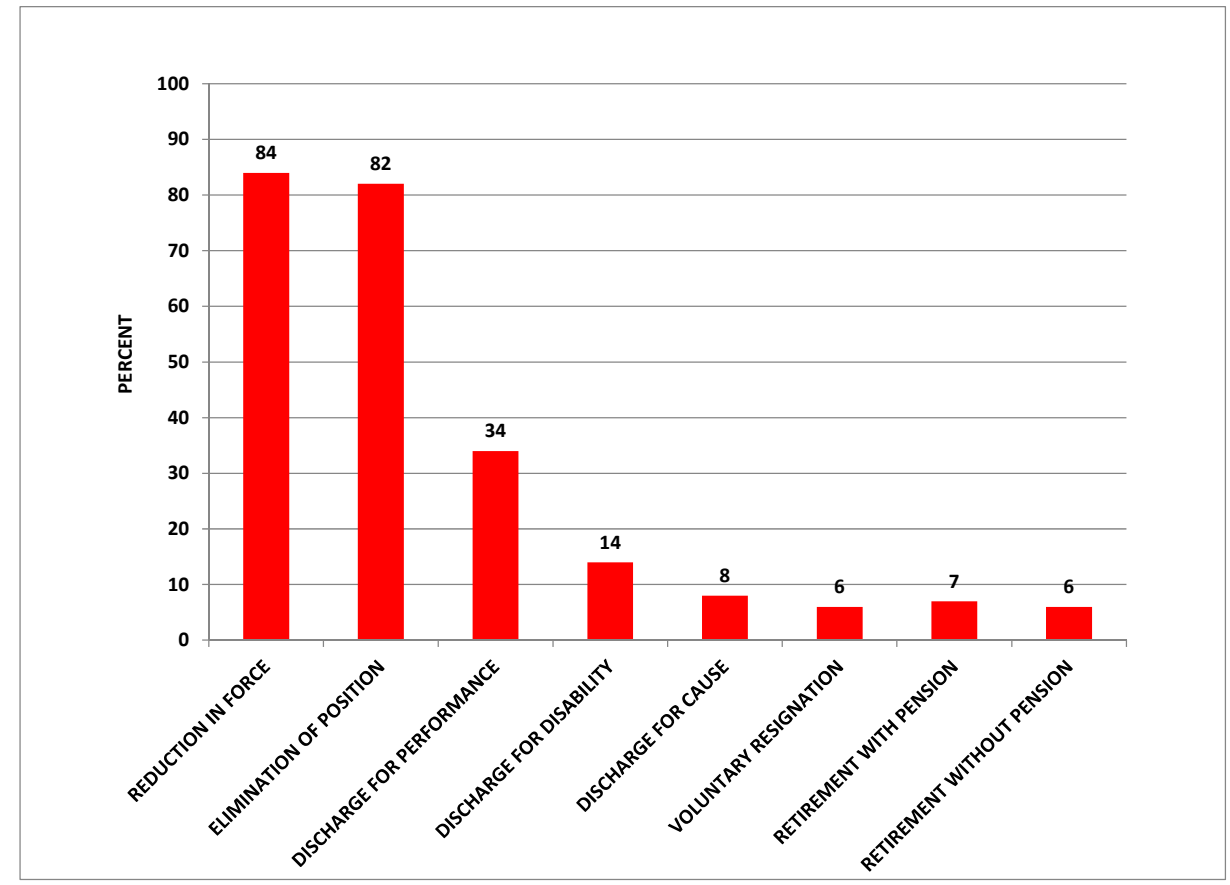

Panel B: International Mandated Severance Plans 142 Countries (2012)

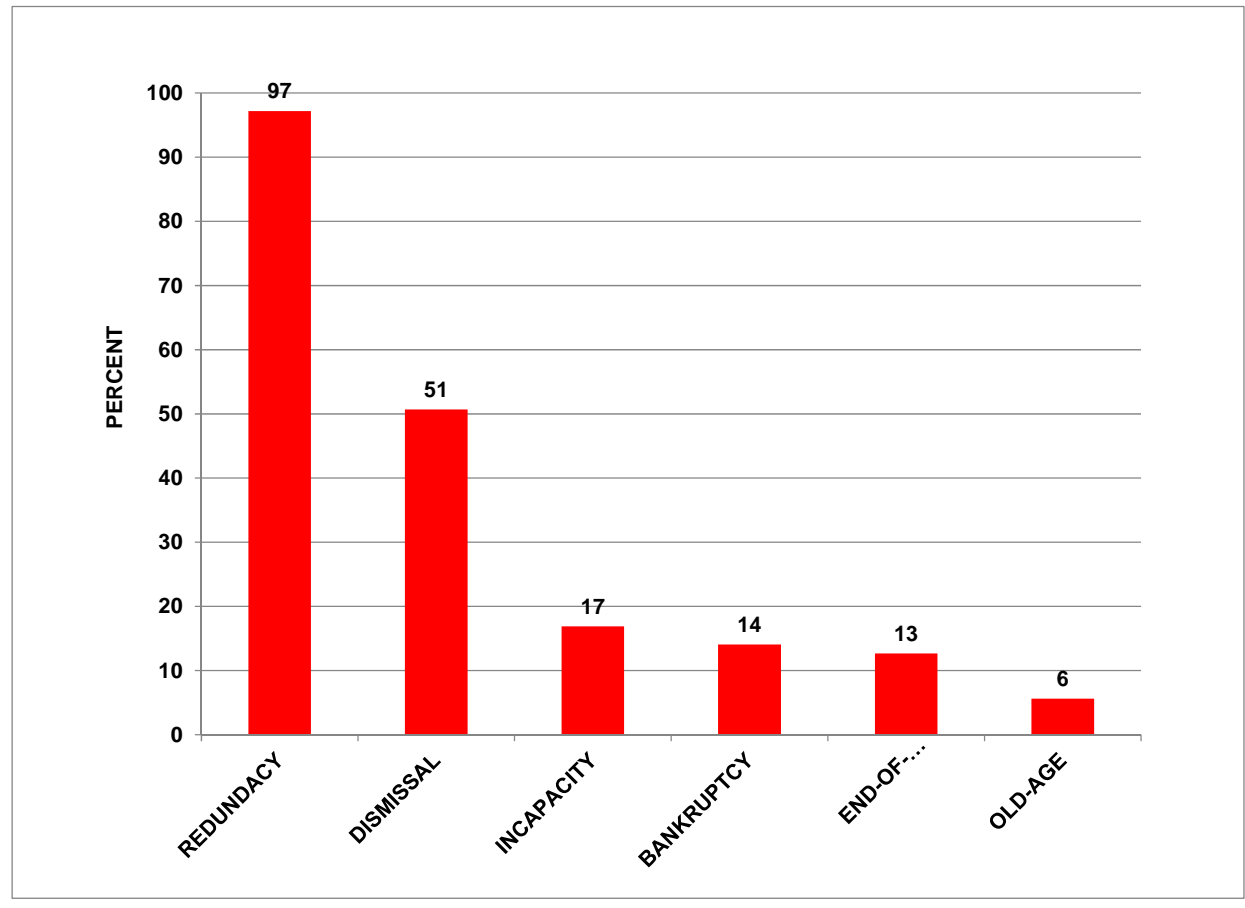

Sources: Panel A: Right Associates (1990); Panel B: Author's Computations from Holzmann et al (2012, Annex B). 